Nurten Karacan Ozdemir

DOI: 10.18290/pepsi-2019-0007

Sylvia C. Nassar

Ersoy Karabay

Ahmet Ayaz*

\title{
Program Evaluation of Career Development Services in Five Turkish Schools: A Preliminary Study
}

\section{ABSTRACT}

School counselors in Turkey, like in many other countries, are tasked with providing career development services within the broader school curriculum. Yet, both globally as well as in Turkey, the unemployment rate among youth continues to rise. In addition, Turkey is home to thousands of Syrian refugees largely concentrated in four cities, creating another layer of challenge for school counselors as career development providers. Effective programs are essential more than ever before, yet very few rigorous efforts at evaluating such programs are in place. In Turkey there are some recent policies governing both career practices and their evaluation, which represents a promising beginning for evaluating these programs locally and nationally. This preliminary qualitative study aims to provide such an example of program evaluation by measuring six key components as identified by the Career Builders Toolkit, an empirically based tool designed to develop and evaluate career and workforce development programs. Five school counseling programs in the city of Gaziantep, Turkey (which is among the cities with a very high Syrian refugee populations), were purposefully selected. Their program materials were content analyzed and, encoded around the Career Builders Toolkit six key components, were rated as

* Correspondence regarding the paper should be sent to: Nurten Karacan Ozdemir, Department of Psychological Counseling and Guidance, Hacettepe University (Turkey), e-mail: nurtenkaracan@hacettepe.edu.tr, or to Sylvia C. Nassar, Department of Educational Leadership, Policy, and Human Development, North Carolina State University (USA), e-mail: snassar@ncsu.edu, or to Ersoy Karabay, Faculty of Education, Kırșehir Ahi Evran University (Turkey), e-mail: e.karabay@ahievran.edu.tr, or to Ahmet Ayaz, Department of Psychological Counseling and Guidance, Hasan Kalyoncu University (Turkey, e-mail: ahmet.ayaz@hku.edu.tr 
being Sufficient, Existing, or Absent, thus providing information about the growth areas still needed in these school-based career development curricula. Among the largest growth areas identified were trainer curriculum and evaluation. Implications for policy, research, and practice are provided based on a Tripartite Model of Program Evaluation.

KEYWORDS: career development programs, program evaluation, school counseling, career practice, the tripartite model, career builders toolkit.

High school years are crucial for career development as well as academic and social/emotional growth of young people (American School Counselor Association [ASCA], 2012). The question is when and how to introduce and prepare youth for the world of work. Being proactive and preventive, school counseling curricula should attend to best practice guidelines in order to maximize positive student outcomes (ASCA, 2012; Whiston, Tai, Rahrdja, \& Eder, 2011).

Similarly, the European Commission pointed out the role of schools in promoting vocational development competencies (Organisation for Economic Co-operation and Development [OECD], 2003). Congruent with international attempts, Turkey has recently identified school counselors' roles as assessing students' academic, social, and career needs, developing school counseling programs accordingly, and continuously evaluating and improving upon these programs (Mesleki Yeterlik Kurumu [MYK], 2017a).

Despite such inherent aims within educational systems, global youth unemployment and poverty rates are increasing at alarming rates in both developing and developed countries (International Labour Organization, 2016). The Turkish Statistics Institution (2017) Youth Report of 2016 indicated that 24\% of youth in Turkey are neither enrolled in education programs nor employed, with a rate of increasing youth unemployment rate by 19.6 percent. Moreover, the refugee crisis created by the 2011 Syrian civil war has dramatically increased Turkey's informal employment sector (Aile ve Sosyal Politikalar Bakanlığı, 2016). Furthermore, 54 percent of Syrian refugees in Turkey are aged 0-18; 830,000 of 
refugee children are school-aged, and the rate of newborn babies has been rapidly increasing since these refugee families have resettled (UNICEF, 2016). These dynamics pose serious implications for the potential workforce of the future and the need for effective career development programs in Turkey.

In Turkish schools, the role of school counselors, and at times, classroom guidance teachers, are prominent in the delivery of both academic and career/guidance services (Korkut, 2007). In sum, career guidance is integrated into the school curriculum in Turkey. Best practice templates are provided by guidance and research centers, and school counselors are tasked with developing their own programs to meet the unique needs of their schools.

The existing literature highlights the importance of program evaluation as well as a connection between policy, research, and practice (Nassar, Al-Qimlass, \& Karacan, 2019). The current preliminary study serves to illustrate a systemic process of evaluating effectiveness of career programs and services incorporated into annual school counseling programs in Turkey. The research questions guiding our preliminary study are: to what extent are the specific evaluation criteria Sufficient, Existent, or $A b$ sent in the career development programs selected for our study. To respond to the increasing demands for effective career development programs (Simons, Goddard, \& Patton, 2000), it is our hope that our study results will inform practitioners (and researchers and policy makers) in their evaluation efforts, and subsequently, to enhance and improve upon their career development programs accordingly.

\section{METHOD}

This study utilized a qualitative study. Document analyses were conducted on annual school counseling programs, specifically by employing content analysis. The sample consisted of five high 
schools purposefully selected from within the city of Gaziantep (Turkey), located in the district with the highest unemployment rates nationally (Turkish Statistics Institution, 2018).

An evaluation tool selected as relevant for this study was the Career Builders Toolkit: A Guide for Creating, Evaluating, and/or Enhancing Career Counseling and Youth Support Programs in Global Workforce Development (Nassar, Al-Qimlass, Tovar, \& KaracanOzdemir, 2017). This tool was developed based on the results of a Delphi study conducted world-wide to attain consensus among experts across policy, research, and practice domains (Nassar, AlQimlass, Karacan-Ozdemir, \& Tovar, 2019). The Toolkit details 41 considerations for career practitioners (also researchers and policy makers), organized around its six key components: 1) Holistic, Systemic, Comprehensive Framework, 2) Needs Assessment, 3) Trainer Curriculum, 4) Participant Curriculum, 5) Delivery, and 6) Program Development. One of the intended uses for the Toolkit is program evaluation, utilizing the following criterion to determine growth needs within career and workforce development programs: Sufficient (2) signifies that there is no additional growth need for that consideration; Existent (1) denotes that the program already has some features included in this consideration but should be improved; and Absent (0) indicates that there is a high need for growth as features addressed within this consideration are lacking.

We obtained school counseling program documents for the 2017-2018 academic term from school counselors across the five participating schools. Based on Schreier's (2014) recommendation, the Toolkit was used as a encoding schema for the evaluation of the programs and by applying the associated evaluation criteria. 


\section{RESULTS AND DISCUSSION}

In this section, we provide a numerical representation of the evaluation of the six Key Components in the Toolkit; along with a subsequent discussion in terms of strengths and weaknesses of the programs regarding their respective career and workforce development interventions (see Table 1 below).

Table 1. Results on the Components and their corresponding considerations.

\begin{tabular}{|l|c|c|c|}
\hline $\begin{array}{l}\text { Component 1: Holistic, Systematic and Comprehensive } \\
\text { Framework }\end{array}$ & Absent & Existing & Sufficient \\
\hline $\begin{array}{l}\text { 1. Include programs that are both developmental } \\
\text { and progressive (age-specific, lifelong). }\end{array}$ & 0 & 1 & 4 \\
\hline $\begin{array}{l}\text { 2. Address the unique characteristics and needs of } \\
\text { the participant groups (customizable, culturally } \\
\text { appropriate). }\end{array}$ & 0 & 1 & 4 \\
\hline $\begin{array}{l}\text { 3. Utilize conventional and new, innovative } \\
\text { theories to inform career and workforce } \\
\text { development programs for youth. }\end{array}$ & 5 & 0 & 0 \\
\hline $\begin{array}{l}\text { 4. Focus on programs, trainings, and information } \\
\text { that have practical applications (evidence-based, } \\
\text { information and/or access to financial services). }\end{array}$ & 0 & 5 & 0 \\
\hline $\begin{array}{l}\text { 5. Be rooted within the community (input } \\
\text { from multiple institutions and organizations, } \\
\text { awareness and support throughout the } \\
\text { community). }\end{array}$ & 0 & 5 & 0 \\
\hline $\begin{array}{l}\text { Component 2: Needs Assessment } \\
\text { 1. Aspects of implementation (process, logistics } \\
\text { and accessibility issues). }\end{array}$ & 3 & 2 & 0 \\
\hline $\begin{array}{l}\text { 2. Include a wide range of factors impacting } \\
\text { youth (talents, skills, values, etc., should consider } \\
\text { challenges that have traditionally impacted } \\
\text { youth). }\end{array}$ & 3 & 2 & 0 \\
\hline $\begin{array}{l}\text { 3. Current state of the community (current/pre- } \\
\text { existing community factors, labor demand, etc.). }\end{array}$ & 2 & 2 & 1 \\
\hline
\end{tabular}




\begin{tabular}{|c|c|c|c|}
\hline $\begin{array}{l}\text { 4. Individual stakeholder groups (parents, } \\
\text { counselors and researchers/scholars). }\end{array}$ & 2 & 2 & 1 \\
\hline $\begin{array}{l}\text { 5. Programmatic stakeholder groups (educational, } \\
\text { employment and social programs, including other } \\
\text { youth and advocacy organizations). }\end{array}$ & 1 & 1 & 3 \\
\hline $\begin{array}{l}\text { 6. Professional stakeholder groups (local and } \\
\text { regional agencies, private sector industry, trade } \\
\text { unions and professional associations). }\end{array}$ & 5 & 0 & 0 \\
\hline $\begin{array}{l}\text { 7. Collaboration between all stakeholders } \\
\text { (system for communication with stakeholders, } \\
\text { and diverse and specific goals agreed upon by } \\
\text { multiple stakeholders). }\end{array}$ & 0 & 5 & 0 \\
\hline \multicolumn{4}{|l|}{ Component 3: Trainer Curriculum } \\
\hline $\begin{array}{l}\text { 1. Utilize the most appropriate personnel in } \\
\text { providing career and workforce development } \\
\text { programs for youth. }\end{array}$ & 5 & 0 & 0 \\
\hline $\begin{array}{l}\text { 2. Include theories and techniques of helping and } \\
\text { career development. }\end{array}$ & 5 & 0 & 0 \\
\hline 3. Develop using multiple sources. & 5 & 0 & 0 \\
\hline 4. Address psychosocial needs. & 2 & 3 & 0 \\
\hline $\begin{array}{l}\text { 5. Include operational and business components } \\
\text { of an effective global youth workforce } \\
\text { development program. }\end{array}$ & 5 & 0 & 0 \\
\hline \multicolumn{4}{|l|}{ Component 4: Participant Curriculum } \\
\hline 1. Develop using multiple sources. & 0 & 4 & 1 \\
\hline $\begin{array}{l}\text { 2. Include a curriculum for parents / family } \\
\text { members. }\end{array}$ & 4 & 0 & 1 \\
\hline $\begin{array}{l}\text { 3. Include a curriculum for other community } \\
\text { members/stakeholders. }\end{array}$ & 5 & 0 & 0 \\
\hline $\begin{array}{l}\text { 4. Recruit target participants through various } \\
\text { avenues. }\end{array}$ & 3 & 1 & 1 \\
\hline $\begin{array}{l}\text { 5. Incorporate effective career education and } \\
\text { guidance components. }\end{array}$ & 0 & 4 & 1 \\
\hline $\begin{array}{l}\text { 6. Incorporate effective technical and vocational } \\
\text { training components. }\end{array}$ & 5 & 0 & 0 \\
\hline
\end{tabular}




\begin{tabular}{|c|c|c|c|}
\hline $\begin{array}{l}\text { 7. Incorporate effective soft skills training } \\
\text { components. }\end{array}$ & 0 & 2 & 3 \\
\hline $\begin{array}{l}\text { 8. Incorporate effective transferable skills training } \\
\text { components. }\end{array}$ & 0 & 4 & 1 \\
\hline \multicolumn{4}{|l|}{ Component 5: Program Delivery } \\
\hline $\begin{array}{l}\text { 1. Respond to the realities of its participants and } \\
\text { the community. }\end{array}$ & 4 & 1 & 0 \\
\hline 2. Be feasible and accessible to its participants. & 0 & 4 & 1 \\
\hline $\begin{array}{l}\text { 3. Include different approaches to curriculum } \\
\text { delivery. }\end{array}$ & 2 & 3 & 0 \\
\hline $\begin{array}{l}\text { 4. Make sure that an effective delivery of } \\
\text { career and workforce development programs } \\
\text { incorporates participants and stakeholders. }\end{array}$ & 1 & 4 & 0 \\
\hline 5. Include individual interventions. & 3 & 1 & 1 \\
\hline 6. Include group interventions. & 0 & 3 & 2 \\
\hline 7. Include peer-to-peer interactions. & 4 & 1 & 0 \\
\hline 8. Incorporate technology. & 1 & 4 & 0 \\
\hline \multicolumn{4}{|l|}{ Component 6: Evaluation } \\
\hline $\begin{array}{l}\text { 1. Utilize the fundamentals as related to its } \\
\text { development and implementation. }\end{array}$ & 0 & 5 & 0 \\
\hline $\begin{array}{l}\text { 2. Utilize clear operational definitions of items to } \\
\text { be measured. }\end{array}$ & 3 & 2 & 0 \\
\hline $\begin{array}{l}\text { 3. Include observations from multiple aspects of } \\
\text { the program. }\end{array}$ & 5 & 0 & 0 \\
\hline $\begin{array}{l}\text { 4. Include intervention research with a view to } \\
\text { analyzing and evaluating the program itself. }\end{array}$ & 5 & 0 & 0 \\
\hline $\begin{array}{l}\text { 6. Include key outputs and outcomes related to } \\
\text { participant variables. }\end{array}$ & 5 & 0 & 0 \\
\hline $\begin{array}{l}\text { 7. Include key outputs and outcomes related to } \\
\text { program and community related variables. }\end{array}$ & 1 & 4 & 0 \\
\hline $\begin{array}{l}\text { 8. Utilize methodological rigor when identifying } \\
\text { and measuring the key outputs and outcomes. }\end{array}$ & 4 & 1 & 0 \\
\hline
\end{tabular}


Component 1 considerations were frequently addressed by the programs. In particular, developmental and progressive characteristics such as being age-specific and lifelong were sufficient as mentioned in the relevant literature. Bimrose, Barnes, and Brown (2005) summarized the characteristics of effective guidance as immediate (e.g., promoting enhancement of skills), intermediate (e.g., supporting career planning activities), and long-term outcomes (e.g., prompting productivity), which implies being progressive and age-specific, and parallels the European Commission's directive that career education and guidance programs apply a developmental approach (OECD, 2003). The programs addressed unique characteristics and needs of the participant groups (e.g., customizable and culturally appropriate programs) sufficiently such as focusing on the reality of Turkish university entrance exams in keeping with the previous literature (Yeşilyaprak, 2012). On the other hand, the consideration of utilizing conventional, new and innovative theories, to our mind, was weakly represented in the programs. Most of them employed traditional trait-and-factor approaches, seemingly inconsistent with prior research findings (e.g., Akkök \& Watts, 2003; Karacan-Ozdemir \& Ayaz, 2018).

A regards Component 2, Needs Assessment, some of the considerations were rated as insufficient, such as implementation (i.e. logistic and accessibility issues), a wide range of factors impacting young people, inclusive of individual or professional stakeholder groups such as parents, teachers, local agencies, etc. Conducting needs assessment has recently become compulsory through a recent regulation of MoNE (2017). In some ways this preliminary study meets that directive.

Component 3, Trainer Curriculum, was largely lacking in the school counseling programs. In particular, the first consideration suggests special training as best practice. In Turkey, school counselors do four-year undergraduate courses to take theoretical and practical classes in vocational guidance. However, profession- 
als affiliated with different disciplines, such as sociology and philosophy, can work as school counselors by only having attended a one-month training course (Doğan, 1998; Stockton \& Yerin-Güneri, 2011). This one-month course is not enough for them to be able to adequately deal with crisis, trauma, and other psychosocial issues. Therefore, it is still necessary to train trainers. The remaining considerations, such as applied and practical theories and techniques, curriculum input from multiple sources and operational and business components (e.g., social entrepreneurial skills, coaching and marketing skills) were absent and not consistent with best practice advice offered by the literature (e.g., OECD, 2003; Hooley, Marriott, Watts, \& Coiffait, 2012) or with the continuous learning competencies expected from career counselors and professionals in Turkey and Europe (e.g., Cedefop, 2009; MYK, 2017b; Schiersmann et al., 2012).

Component 5, Program Delivery, was represented across programs, but not sufficiently. For instance, the criteria that responding to the realities of students and schools (e.g., socio-economic conditions, feasibility and accessibility, inclusion of individual and group interventions, and incorporation of technology) were all observed in the programs. Yet, the existing literature underscores the criticality of addressing career developmental needs and barriers of different cultural groups in counseling programs and the entire K-12 curriculum (Mau \& Bilkos, 2000; Krass \& Hughey, 1999). The school programs were chosen from Gaziantep which has absorbed $19.22 \%$ of Syrian refugees (Ministry of Interior Directorate General of Migration Management, 2017), with 1515 Syrian students enrolled in its schools in 2014 (Sandal, Hançerkıran, \& Tiraş, 2016). It does not appear that these programs responded adequately to the realities of the refugee crisis within its community. Another consideration that was deemed weak in the programs is the incorporation of technology, which is not inconsistent with the situation in other areas of Turkey (Yeşilyaprak, 2017) and also in many other countries (Bimrose et al., 2005; Institute of 
Educational Sciences, 2012). The National Vocational Information System (NVIS), launched in 2010 through MoNE as an online career assessment and planning platform (Korkut-Owen \& Yerin Güneri, 2015), was almost the only web-based technology incorporated in the school programs.

Most critically, Evaluation was assessed as the sixth and final key consideration for effective career and workforce development programs. The use of the fundamentals for developing and implementing programs (such as determining common goals and outcomes regarding the program and community) and the employment of simple evaluation tools were represented in the programs, but not sufficiently. For instance, school guidance committees met at the beginning of the academic year to consider student needs and to set goals accordingly, and eventually evaluate the programs and interventions applied. In addition, the evaluations required by the MoNE annually only reflect outputs (e.g., numeric values of interventions and attendees (see http:/ / orgm.meb.gov.tr/) rather than detailed evaluation data such as that referenced in the Tookit. Despite the oft-cited need for stronger evaluation of career guidance programs (e.g., Baudouin et al., 2007), our finding is consistent with the prior research findings in Turkey and elsewhere underscoring the need for better comprehensive evaluation (e.g., Akkök \& Watts, 2003; Akkök, 2006). For example, while one study suggested that nearly $35 \%$ of practitioners reported evaluating their work (Lalande, Hiebert, Magnusson, Bezanson, \& Borgen, 2006); another study showed that $40 \%$ of them did not (Conger, Hiebert, \& Hong-Farrell, 1994).

\section{CONCLUSION}

This preliminary study sought to evaluate school counseling programs in terms of career and workforce development interventions in five Turkish schools. As mentioned in the introductory 
section, program evaluation efforts are the most effective if they are carried out across the three inter-connected domains of policy, research, and practice, as shown in Figure 1, the Tripartite Model of Program Evaluation. The evaluation process should be guided by best practices such as those of provided nationally in Turkey, inform the synergistic connection across the three domains, and ultimately yield reiterative best practices. Below are some implications for each of these inter-connected domains as well as some prospective best practices that this preliminary program evaluation study indicates.

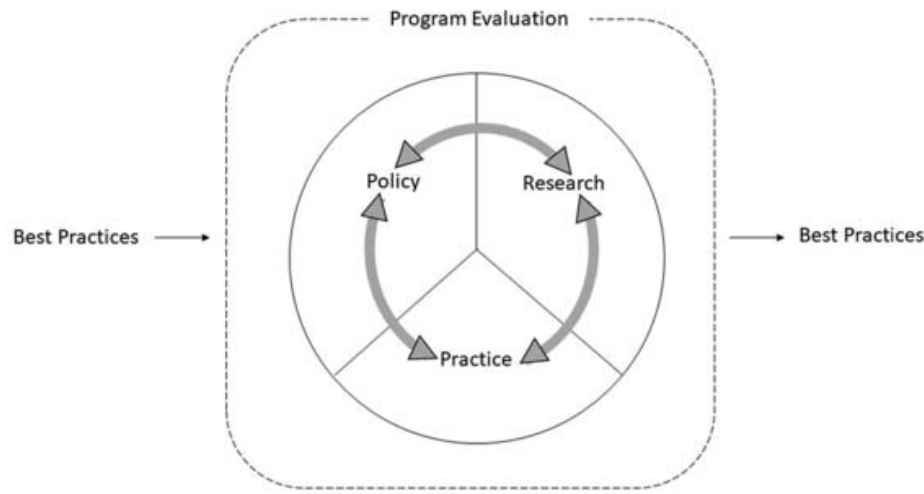

Figure 1. Tripartite Model of Program Evaluation (Nassar, Al-Qimlass, \& Karacan-Ozdemir, 2019).

In Turkey, the provision of career counseling and guidance is one of the main tasks of school counselors (Yerin-Güneri, Büyükgöze Kavas, \& Koydemir, 2007), and as such is integrated into annual school guidance programs. This preliminary examination of five Turkish schools suggests that the career services in the schools evaluated are more or less adequate in their response to the realities of the surrounding community and the broader Turkish education system, especially in implementing age-specific, life-long programs. In addition, most likely in response to re- 
cently mandated policies, to some extent the programs included needs assessment procedures and included community, schools, and teachers. At the same time, they still lack parental involvement, which needs to be better incorporated. Another finding of this preliminary study is that there is the still critical need for systematic evaluation of the programs. As prescribed in the Career Builders Toolkit, school counselors should be mindful of implicit and explicit purposes of their programs and then outline expected outputs and outcomes accordingly. They can also elect to incorporate other considerations provided within the evaluation component of this tool to evaluate and improve their evaluation method and process. What is more, MoNE can use the findings of this preliminary study to improve its evaluation template for school counselors to gather better information that can be more relevant for the guiding policy-makers. Furthermore, this study implied a need for those professionals in school counseling roles who do not have the traditional educational training in school counseling. This also represents a critical initiative that will need to be driven by a policy change and corresponding national funding. In summary, while the programs that were evaluated in this preliminary study are providing adequate services, there are several areas in need of enhancement and improvement.

In summary, several limitations of the study should be pointed out. The sample consisted of only five Anatolian high schools in Gaziantep, a city in eastern Turkey, where the Syrian refugee population is exceptionally high, thus the findings cannot be generalized for other regions. Nevertheless, future research can evaluate the programs from other types of high schools such as science, art, and vocational high schools as well as schools from different regions of Turkey. Next, this study assumed that school counselors' self-reports provided an accurate representation of their school-based career guidance services. Future developments in program evaluation of career and guidance interventions in Turkish schools could involve a Turkish version of the Career 
Builders Toolkit so that school counselors will be empowered to evaluate their own program initiatives and efforts.

\section{REFERENCES}

Aile ve Sosyal Politikalar Bakanlığı. (2016). Türkiye'de Geçici Koruma Statüsündeki Suriye Vatandaşlarına Yönelik Sosyal Uyum ve Psikososyal Destek Çalışmaları Koordinasyon ve Planlama Çalıştay Raporu. Retrieved from https:/ / ailetoplum.aile.gov.tr/data/5429366a369dc32358ee2a92/calistay _raporu.pdf

Akkök, F., \& Watts, A. G. (2003). Public policies and career development: A framework for the design of career information, guidance and counseling services in developing and transition countries. Country report on Turkey. World Bank. Retrieved from http://siteresources.worldbank.org/INTLL/Resources/Public-Policies-andCareer-Development-Policy/Turkey_report.pdf

Akkök, F. (2006). Mesleki bilgi, rehberlik ve danışmanlık hizmetleri Türkiye ülke raporu. Ankara, Turkey: İŞKUR Dökümanları.

American School Counselor Association. (2012). ASCA National Model: A framework for school counseling. Alexandria, VA: Author.

Baudouin, R., Bezanson, L., Borgen, B., Goyer, L., Hiebert, B., Lalande, V., \& Turcotte, M. (2007). Demonstrating value: A draft framework for evaluating the effectiveness of career development interventions. Canadian Journal of Counselling, 41(3), 146-157.

Bimrose, J., Barnes, S., \& Brown, J. (2005). A systematic literature review of research into career-related interventions for higher education. Institute for Employment Research, University of Warwick, Coventry, England.

European Centre for the Development of Vocational Training. (2009). Professionalising career guidance: Practitioner competences and qualification routes in Europe (Cedefop Panorama Series, 164). Luxembourg: Office for Official Publications of the European Communities. Retrieved from www.cedefop. europa.eu/files/5193_en.pdf

Conger, D.S., Hiebert, B., \& Hong-Farrell, E. (1994). Career and employment counselling in Canada. Ottawa: Canadian Labour Force Development Board. Retrieved from https:/ / files.eric.ed.gov/fulltext/ED375336.pdf

Doğan, S. (1998). Counseling in Turkey: Current status and future challenges. Education Policy Analysis Archives, 6, 1-12. 
Hooley, T., Marriott, J., Watts, A. G., \& Coiffait, L. (2012). Careers 2020: Options for future careers work in English schools. London, England: Pearson.

Institute of Educational Sciences (2012). Good practices in the use of ICT in providing guidance and counselling. Retrieved from http://www.jobtribu.eu/pdf/ JT_ICT_Goodpractices_web.pdf

International Labour Organization. (2016). Interventions to improve the labour market outcomes of youth: A systematic review of training, entrepreneurship promotion, employment services and subsidized employment interventions. Retrieved from http://www.ilo.org/employment/Whatwedo/Publications/ WCMS_508938/lang--en/index.htm

Karacan-Ozdemir, N., \& Ayaz, A. (2018). School counseling and guidance programs: Examination of career adaptabilities. Hacettepe University Journal of Education. Advance online publication. doi:10.16986/HUJE.2018045437

Korkut, F. (2007). Counsellors' thoughts and practices regarding career guidance and counselling. Journal of Hacettepe University Education Faculty, 32, 187-197.

Korkut-Owen, F., \& Yerin-Güneri, O. (2013). Counseling in Turkey. In T.H. Hohenshil, N.E. Amundson, \& S.E. Niles (Eds.), Counseling around the world: An international handbook (pp. 293-302). Alexandria, VA: ACA.

Krass, L., \& Hugley, K. (1999). The impact of an intervention on career decisionmaking self-efficacy and career indecision. Professional School Counseling, 2(5), 384-396.

Lalande, V., Hiebert, B., Magnusson, K., Bezanson, L., \& Borgen, B. (2006). Measuring the impact of career services: Current and desired practices. NATCON Papers 2006. Retrieved from http://citeseerx.ist.psu.edu/viewdoc/downl oad?doi=10.1.1.617.1883\&rep=rep1\&type $=$ pdf

Mau, W., \& Bikos, L. (2000). Educational and vocational aspirations of minority and female students: A longitudinal study. Journal of Counseling \& Development, 78, 186-194.

Mesleki Yeterlik Kurumu. (2017a). Ulusal meslek standardı, okul psikolojik danışmanı [National Occupational Standards, School Counselor]. T.C. Resmi Gazete, 30227.

Mesleki Yeterlik Kurumu. (2017b). Ulusal meslek standard1, kariyer psikolojik danışmanı [National Occupational Standards, Career Counselor]. T.C. Resmi Gazete, 30227.

Ministry of Interior Directorate General of Migration Management. (2017). The report of executive action. Retrieved from http:/ / www.goc.gov.tr/files/files/ Goc_\%20idaresi_2017_.pdf

Ministry of National Education. (2017). Rehberlik ve psikolojik danışma hizmetleri plan hazırlama kitapçı̆̆ [The booklet for preparing school 
counseling annual plan]. Retrieved from http://orgm.meb.gov.tr/www/ rehberlik-hizmetleri-plan-hazirlama-kitapcigi-guncel/icerik/998

Nassar, S., Al-Qimlass, A., \& Karacan-Ozdemir, N. (2019). A tripartite model of program evaluation: Implications for effective career services and workforce development. International Journal for Educational and Vocational Guidance (published online).

Nassar, S., Al-Qimlass, A., Karacan-Ozdemir, N., \& Tovar, L. (2019). Guidelines for career intervention services in global workforce development: Consensus across policy, research, and practice. Empirical Research in Vocational Education and Training, 11(5). doi:10.1186/s40461-019-0080-4

Nassar, S., Al-Qimlass, A., Tovar, L., \& Karacan Ozdemir, N. (2017). Career builders toolkit: A guide for creating, evaluating, and/or enhancing career counseling and youth support programs in global workforce development. Research Triangle Institute, North Carolina State University. Retrieved from http:/ gcyerti. com/projects-publications/projects-publications

Organisation for Economic Co-operation and Development. (2003). Career guidance: New ways forward. In Education policy analysis (pp. 39-57). Retrieved from http://www.oecd.org/edu/innovation-education/19975192.pdf

Sandal, E. K., Hançerkıran, M., \& Tıraş, M. (2016). Syrian Refugees in Turkey and Their Reflections in Gaziantep Province. Gaziantep University Journal of Social Sciences, 15(2), 461-483.

Network for Innovation in Career Guidance and Counselling in Europe. (2012). NICE handbook for the academic training of career guidance and counselling professionals (edited by C. Schiersmann, B.-J. Ertelt, J. Katsarov, R. Mulvey, H. Reid, \& P. Weber). Heidelberg, Germany: Heidelberg University.

Schreier, M. (2014). Qualitative content analysis. In U. Flick (Ed.), The Sage handbook of qualitative data analysis (pp. 170-183). Los Angeles, CA: Sage.

Simons, R., Goddard, R., \& Patton, W. (2000). Measuring vocational interests: A call for multi-sample norms. Career Development International, 5(7), 351-359.

Stockton, R., \& Yerin Güneri, O. (2011). Counseling in Turkey: An evolving field. Journal of Counseling \& Development, 89, 98-104. doi:10.1002/j.1556-6678.2011. tb00065

Turkish Statistics Institution (2017). Türkiye İstatistik Kurumu İstatistiklerle Gençlik 2016 Raporu [Youth Report of 2016]. http:/ /www.tuik.gov.tr/PreHaberBultenleri.do?id=24648

Turkish Statistics Institution (2018). İşgücü İstatistikleri 2017 [Workforce Statistics of 2017]. http:/ / www.tuik.gov.tr/HbGetirHTML.do?id=27699

UNICEF. (2016). Türkiye'deki Suriyeli Çocuklar [Syrian Children in Turkey]. Retrieved from http://unicef.org.tr/files/bilgimerkezi/doc/T\%C3\% 
BCrkiyedeki $\% 20$ Suriyeli $\% 20 \%$ C3\%87ocuklar_Bilgi $\% 20$ Notu $\% 20$ Subat $\% 20$ 2016.pdf

Whiston, S. C., Tai, L. W., Rahrdja, D., \& Eder, K. (2011). School counseling outcome: A meta-analytic examination of interventions. Journal of Counseling \& Development, 89(1), 37-55. doi:10.1002/j.1556-6678.2011.tb00059.x

Yerin-Güneri, O., Büyükgöze-Kavas, A., \& Koydemir, S. (2007). Okul psikolojik danışmanlarının profesyonel gelişimi: Acemilikten olgunlaşmaya giden zorlu yol. In D. Owen, F. Korkut-Owen, \& R. Özyürek (Eds.), Gelişen psikolojik danışma ve rehberlik: Meslekleşme sürecindeki ilerlemeler (pp. 139-162). Ankara, Turkey: Nobel.

Yeşilyaprak, B. (2012). The paradigm shift of vocational guidance and career counseling and its implications for Turkey: An evaluation from past to future. Educational Sciences: Theory \& Practice, 12(1), 97-118.

Yeşilyaprak, B. (2017). Career counselling services in Turkey: Building on the past and constructing the future. In R. Sultana (Ed.), Career guidance and livelihood planning across the Mediterranean (pp. 267-282). Rotterdam, Netherlands: Sense Publisher. 